ISSN : $1979-7362$

\title{
Pengaruh Penggunaan Zat Etefon Terhadap Sifat Fisik Pisang Kepok (Musa Paradisiaca L)
}

\author{
Ari Wirasaputra ${ }^{1}$, Mursalim ${ }^{1}$ dan Waris ${ }^{1}$
}

Program Studi Teknik Pertanian, Universitas Hasanuddin Makassar

\begin{abstract}
ABSTRAK
Buah pisang menempati posisi pertama dengan produksi dan luas panen tertinggi di Indonesia. Pada tahun 2002 produksinya mencapai 4.384.384 ton dengan nilai ekonomi sebesar Rp 6,5 triliun. Pisang di Indonesia juga dimanfaatkan sebagai bahan baku industri olahan pisang misalnya Pisang Epe, Pisang Ijo, Barongko, Es Palubutung dan tepung pisang. Hal itu menyebabkan tingginya permintaan buah pisang yang sudah matang sehingga pedagang biasanya melakukan pematangan buah dengan metode zat etefon. Sehingga perlu dilakukan efek mutu dan konsentrasi penelitian menggunakan zat etefon dengan formulasi yaitu $10 \mathrm{ml}, 15 \mathrm{ml}, 20 \mathrm{ml}, 25 \mathrm{ml}$, dan $30 \mathrm{ml}$. Buah pisang lalu direndam untuk membandingkan pengaruh banyakanya formulasi zat etefon terhadap perubahan warna $\left(\mathrm{L}^{*}, \mathrm{a}^{*}, \mathrm{~b}^{*}\right)$ dan bobot buah pisang selama dua minggu penyimpanan.

Buah pisang dengan formulasi zat etefon $30 \mathrm{ml}$ menunjukkan perubahan pematangan buah pisang cenderung lebih cepat dari pada formulasi lainnya. Hal tersebut terlihat pada nilai $\mathrm{L}^{*}$ buah yang cenderung lebih tinggi yaitu 60,18 pada hari ke tiga penyimpanan. Meskipun demikian, nilai a* tertinggi terjadi pada formulasi $15 \mathrm{ml}$ yaitu mencapai 15.68 pada hari ke delapan penyimpanan. Sedangkan nilai $b^{*}$ tertinggi terjadi pada buah dengan formulasi $30 \mathrm{ml}$ yaitu mencapai 27,35 pada hari ke depalan penyimpanan. Adapun susut bobot tertinggi yaitu 53,06 pada hari ke-14 penyimpanan. Hal ini terjadi pada buah pisang yang digunakan sebagai kontrol yaitu buah yang tidak direndam pada zat etefon.
\end{abstract}

Kata Kunci : Pisang Kepok, etefon, perubahan susut bobot, Warna

\section{PENDAHULUAN}

\section{Latar Belakang}

Indonesia merupakan salah satu negara yang mempunyai bidang perkebunan yang mempunyai Luas panen dan produksi pisang selalu menempati posisi pertama. Pada tahun 2002 produksinya mencapai 4.384.384 ton dengan nilai ekonomi sebesar Rp 6,5 triliun. Produksi tersebut sebagian besar dipanen dari pertanaman kebun rakyat seluas 269.000 ha.

Semakin hari semakin banyak jumlah penduduk di Indonesia, dan permintaan buah pisang semakin meningkat, maka akan bertambah pula jumlah pisang matang yang di butuhkan masyarakat Indonesia. Pisang di Indonesia juga dimanfaatkan sebagai bahan baku industri olahan pisang misalnya Pisang Epe, Pisang Ijo, Barongko, Es Palubutung, dan tepung pisang. Perkembangan kebun rakyat dan industri olahan di daerah sentra produksi, dapat memberikan peluang baik secara langsung maupun tidak langsung terhadap perluasan kesempatan berusaha dan kesempatan kerja.

Pematangan buah biasanya di lakukan dengan metode tradisional dan metode karbit. Metode tradisonal dengan cara buah pisang diperam dalam tempayan yang terbuat dari tanah liat. Kemudian disusun di dalam tempayan dan ditutup dengan kuali, agarudara tidak keluar. Antara tempayan dan kuali diberi tanah liat dan dibakar, agar udara di dalam tempayan menjadi panas, sehingga buah menjadi cepat matang. Metode karbit dengan cara pisang yang sudah di panen di susun di atas terpal dan di di beri karbit di setiap sudut pisang setelah itu di tutup menggunakan terpal. Maka perlu penelitian pematangan pisang menggunakan zatEtefon, guna zat 
Etefon tersebut untuk mempercepat pematangan pisang.

Faktor warna yang sangat penting dalam pengolahan bahan pangan. Konsumen umumnya melakukan penilaian untuk membeli berdasarkan penampakan visual dari bahan pangan itu sendiri. Terkadang, warna atau kenampakan visual tersebut dikaitkan dengan kualitas dari bahan.

Maka perlu dilakukan percobaan mematangkan pisang dengan menggunakan enam varietas pisang yang masingmasinglima diberi larutan zat Etefon perlakuan yang beda dan satu pisang tidak di beri perlakuan atau sebagai kontrol agar kita dapatagar kita dapat mengetahui pisang yang mana yang lebih cepat masak.

Berdasarkan uraian yang telah di jelaskan sebelumnya, maka penulis menganggap penting untuk dilakukan pemantangan pisang agar masyarakatIndonesia dapat tau cara mematangkan pisang dengan cepat.

\section{Tujuan dan Kegunaan Penelitian}

Penelitian ini bertujuan untuk mengetahui besar konsentrasi penggunaan larutan zat pengatur tumbuh yang tepat dalam proses pematangan buah pisang.

Kegunaan penelitian ini adalah sebagai bahan informasi kepada masyarakat Indonesia cara mematangkan pisang dengan menggunakan cairan zat Etefon dengan takaran yang tepat.

\section{TINJAUAN PUSTAKA}

\section{Pisang}

Pisang merupakan buah yang banyak tumbuh di Indonesia. Indonesia juga merupakan salah satu negara yang dikenal sebagai produsen pisang dunia. Indonesia telah memproduksi sebanyak 6,20\% dari total produksi dunia, $50 \%$ produksi pisang Asia berasal dari Indonesia. Sulawesi Selatan adalah pulau diluar Jawa penghasil pisang terbesar yaitu 183,853 ton (Sahutu dan Supriyadi, 2008).

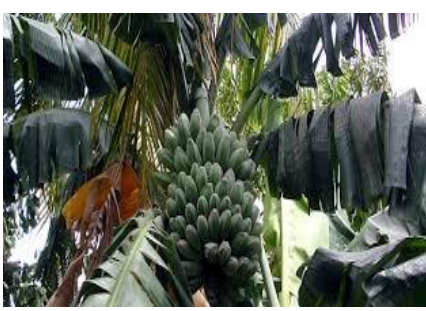

Gambar 1. Pohon Pisang Kepok (Supriyadi, 2008)

Pisang dapat digunakan sebagai alternatif pangan pokok karena mangandung karbohidrat yang tinggi, sehingga dapat menggantikan sebagian konsumsi beras dan terigu. Untuk keperluan tersebut, digunakan buah pisang mentah yang kemudian diolah menjadi berbagai produk, baik melalui pembuatan gaplek dan tepungnya maupun olahan langsung dari buahnya seperti sale pisang, dodol pisang, sari buah pisang dan juga keripik pisang (Sulusi et al,2008).

\section{Pisang Kepok}

Pisang kepok di Filipina di kenal sebagai pisang saba, sedang di malaysia di kenal sebagai pisang nipah. Buahnya enak di makan setelah diolah terlebih dahulu. Bentuk buahnya agak pipih sehingga kadang di sebut buah gepeng. Beratnya pertandan dapat mencapai $14-22 \mathrm{~kg}$ dengan jumlah sisir 10-16. Setiap sisir terdiri dari 12-20 buah. Bila matang warna kulitnya buahnya kuning penuh (Satuhu, 1996).

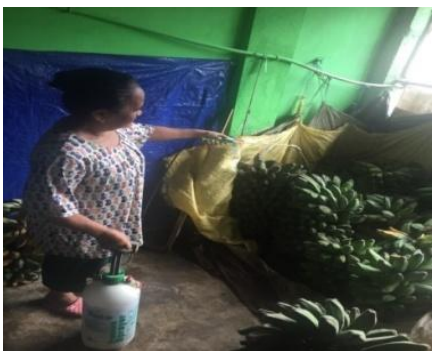

Gambar 2 Penyemprotan Zat Etefon pada buah pisang

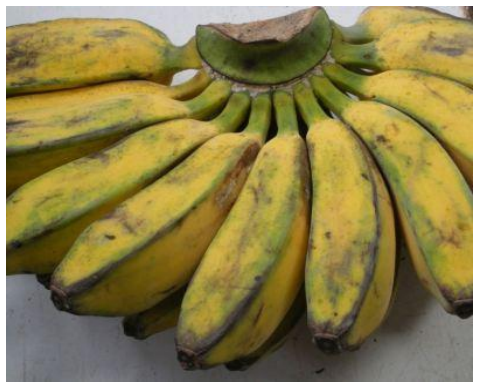

Gambar 3. Pisang Kepok (Sahutu,1996) 
Pisang kepok banyak jenisnya. Yang terkenal diantara lain pisang kepok putih dan kuning. Pisang kepok putih warna dagingnya putih dan pisang kepok kuning warna dagingnya kuning. Pisang kepok kuning mempunyai rasa yang lebih enak dibanding pisang kepok putih. Karenanya, pisang jenis kepok kuning lebih disukai (Satuhu, 1996).

\section{Sifat Fisik Buah pisang}

Sifat fisik bahan hasil pertanian merupakan faktor yang sangat penting dalam menangani masalah-masalah yang berhubungan dengan merancang suatu alat khusus untuk suatu produk hasil pertanian atau analisa prilaku produk dan cara penanganannya. Bentuk, ukuran, volume, masa, luas permukaan, porositas, warna, densitas sangat penting dalam perancangan alsin atau analisis prilaku produk dalam proses penanganannya (Suharto, 1991).

\section{Bobot/Berat Buah}

Selama proses penyimpanan buah akan terjadi susut bobot yang disebabkan hilangnya air dalam proses transpirasi dan respirasi. Ini menyebabkan susut bobot akan bertambah seiring lamanya penyimpanan.Terdapat perbedaan susut bobot yang cukup tinggi, berkisar 1- 3 kali lipat antara susut bobot buah yang disimpan pada suhu kamar dan suhu dingin dimana buah yang disimpan pada suhu kamar lebih cepat mengalami susut bobot dibandingkan buah yang disimpan pada suhu dingin (Pangestuti, 2004).

2. Warna

Warna merupakan salah satu faktor sensori yang mempengaruhi penerimaan produk pangan (Holinesti, 2009). Warna suatu bahan dapat diukur dengan menggunakan alat kolorimeter, spektrometer, atau alat-alat lain yang dirancang khusus untuk mengukur warna. Tetapi alat-alat tersebut biasanya terbatas penggunaannya untuk bahan cair yang tembus cahaya seperti sari buah, bir atau warna hasil ekstraksi.
Untuk bahan cairan yang tidak tembus cahaya atau padatan, warna bahan dapat diukur dengan membandingkannya terhadap suatu warna standar yang dinyatakan dalam angka-angka (Hardiyanti, 2009).

Warna bahan makanan biasanya diukur dalam unit $\mathrm{L}^{*} \mathrm{a} * \mathrm{~b}^{*}$ yang merupakan standar internasional pengukuran warna, diadopsi oleh CIE (Commission Internationale d'Eclairage). Penerangan atau Lightness (L) berkisar antara 0 dan 100 sedangkan parameter kromatik (a, b) berkisar antara -120 and 120 (Gokmen, 2007).

\section{Penanganan Buah Pisang}

1. Penentuan untuk di Panen

Beberapa tanda atau ciri sering digunakan sebagai kriteria untuk memutuskan buah pisang dapat dipanen. Petani seringkali menentukan berdasarkan pengalaman dengan ciri-ciri fisik pada buah, meliputi bentuk buah, ukuran, dan warna kulit buahnya. Untuk memastikan ketuaan panen yang tepat juga perlu didukung analisis komponen penting sebagai penentu seperti kadar padatan terlarut total, kadar pati, dan kadar asamnya (Murtiningsih, 1990).

2. Cara Panen

Setelah buah yang akan dipanen ditentukan tingkat ketuaannya dan sudah memenuhi syarat, maka batang pohon dipotong pada posisi ketinggian sekitar satu meter, kemudian dipotong setengah diameter batangnya dan pohon direbahkan. Tandan pisang dipotong setelah pohon rebah, dan dijaga agar buah pisang tidak terkena getah (Muhajir dan Sanuki, 1998).

3. Pengumpulan dan Pengangkutan

Penangan buah pisang oleh petani maupun pedagang pengepul masih sederhana. Untuk mempertahankan mutu buah pisang setelah panen, maka penanganan yang baik harus dilakukan sejak panen. Buah setelah panen dikumpulkan di tempat 
yang teduh, terlindung dari panas. Umumnya para pedagang pengumpul memiliki ruangan didepan atau disamping rumahnya untuk menampung buah pisang. Tandan buah pisang diletakkan berjajar, tidak bertumpuk, dan harus dihindari penetesan getah dari tangkai yang menodai buah pisang, karena penampilan buah menjadi kotor (Muhajir dan Sanuki, 1998).

4. Pemotongan Sisir dan Pencucian

Untuk menjaga kualitas buah pisang, cara terbaik dalam pengiriman buah adalah dalam bentuk sisir yang dikemas dalam peti karton atau peti plastik yang bisa digunakan ulang. Pekerjaan pemotongan sisir dilakukan oleh pekerja di bangsal pengemasan menggunakan pisau khusus (dehander). Biasanya pada saat dipotong, tiap sisir akan mengeluarkan getah. Untuk membekukan getah dan sekaligus membersihkan debu dan kotoran yang melekat pada permukaan buah, sisirsisir pisang segera dimasukkan dalam bak berisi air. Jika satu sisir pisang berukuran besar dan berisi banyak, maka perlu dipotong lagi atau dalam bentuk klaster, agar lebihmudah penanganannya saat pengemasan (Murtiningsih, et al, 1991).

5. Penyakit Pascapanen yang Menyerang Buah Pisang

Kualitas buah pisang di indonesia kadang kurang baik, yang disebabkan oleh panen tidak tepat waktu (ketuaan tidak memenuhi syarat), kurangnya perawatan tanaman dan buruknya penanganan di kebun dan selama pengangkutan yang mengakibatkan kerusakan mekanis dan memberi peluang infeksi mikroorganisme penyebab busuk pasca panen lebih besar. Selain mikroorganisme yang masuk ke dalam buah melalui luka, serangan busuk buah juga sudah dimulai penetrasinya sejak buah masih di pohon. Mikroorganisme yang telah melakukan penetrasi tersebut adalah colletotrichum sp, yang kemudian berada dalam keadaan laten, dan spora berkecambah saat buah menjadi matang. Pada umumnya busuk pada pisang di indonesia adalah antraknos, tip rot, dan crown rot (Murtiningsih, et al., 1995).

6. Cara Mengatasi Serangan Penyakit Pascapanen

Untuk mengendalikan busuk yang disebabkan serangan penyakit pascapanen dapat digunakan salah satu dari beberapa fungisida atau tanpa bahan kimia yaitu menggunakan pencelupan dengan air panas. Jika tidak ingin menggunakan fungisida, maka perlakuan dengan air panas sudah dapat membantu mengurangi dan menunda serangan busuk pada buah pisang. Pengendalian busuk pada pisang Raja Sere, emas dan lampung telah dilakukan penelitiannya menggunakan beberapa perlakuan yaitu benomil $500 \mathrm{ppm}$, zineb 1000 ppm, mankozeb 1000 ppm, dan perlakuan perendaman dalam air panas $55^{\circ} \mathrm{C}$ selama 2 menit (Suyanti dan Sabari, 1988).

\section{Zat Perangsang Pemasakan}

\section{(Pematangan) Buah}

Bahan ini bisa membuat buah masak lebih serempak, warnanya lebih merata sehingga lebih menarik. Salah satu cara penguningan dan pemasakan buah adalah dengan menggunakan dari zat penghasil etilen. Bahan aktifnya adalah Etefon. Sebuah zat yang sangat asam, dengan $\mathrm{pH}$ 2,0 (Ngasih, 2014).

Zat pengatur tumbuh (ZPT) memiliki peran yang sangat penting bagi pertumbuhan dan perkembangan tanaman. Zat pengatur tumbuh atau hormon (fitohormon) tumbuhan merupakan senyawa organic yang bukan hara, ZPT dalam jumlah sedikit dapat memacu, menghambat dan dapat merubah proses fisiologi tumbuhan. Zat pengatur tumbuh memberikan kontribusi penting dalam dunia pertanian. Pemahaman tentang fungsi dan peran hormon terhadap pertumbuhan dan perkembangan tanaman adalah hal yang 
wajib untuk di pelajari. Sebab menggunakan hormon tersebut harus dilakukan dengan tepat (Azzamy, 2015).

\section{METODE PENELITIAN}

\section{Waktu dan Tempat}

Penelitian ini akan dilaksanakan pada tanggal 16 Agustus sampai 30 Agustus 2016 penelitian ini dilakukan di Laboratorium Mekanika Fluida Jurusan Teknologi Pertanian Universitas Hasanuddin. Makassar

\section{Alat dan Bahan}

Alat yang di gunakan dalam penelitian ini adalah Timbangan Digital, Colorimeter, Termometer, ember, gunting, tissue, gelas ukur, pipet tetes.

Bahan yang digunakan buah pisang yang sudah tua, zat Etefon, air.

\section{Parameter Penelitian}

1. Sifat Fisik Buah

a. Berat/bobot buah

Mengukur berat/bobot buah menggunakan timbangan digital. Menurut Enrico (2008), hasil penimbangan dinyatakan dalam persen bobot yang dihitung dengan rumus:

Susut Bobot $(\%)=\frac{W o-W n}{W o} \times 100 \%$

Dimana :

Wo = bobot awal buah

$\mathrm{Wn}=$ Bobot buah pada hari ke $-\mathrm{n}$

b. Warna

Menurut Hardiyanti (2009) perubahan warna dapat di ukur menggunakan alat ukur warna dengan keluaran nilai Lab, yaitu colorimeter.

\section{Prosedur Penelitian}

1. Persiapan Bahan

a. Menyiapkan pisang 6 buah yang baru saja di panen, satu untuk kontrol.

b. Menyiapkan $5000 \mathrm{ml}$ air dan menambahkan zat Etefon di wadah yang berbeda menggunakan perbandingan $10 \mathrm{ml}, 15 \mathrm{ml}, 20 \mathrm{ml}$, $25 \mathrm{ml}, 30 \mathrm{ml}$.

c. Memasukkan campuran air dan zat Etefon ke dalam ember.

d. Rendam pisang kedalam air selama 20 detik yang sudah di beri zat Etefon setelah itu di simpan di wadah.

e. Penyimpanan menggunakan suhu ruangan.

f. Amati perubahan warna pisang setiap 6 jam sekali selama pisang berubah sampai masak.

2. Pengamatan Perubahan Fisik Buah

Menghitung bobot buah pisang dengan menimbang berat awal dan menimbangnya setiap 6 jam sekali.

3. Pengamatan Perubahan Warna

a. Mengamati perubahan warna buah menggunakan colorimeter

b. Masing - masing pengukuran warna dilakukan 6 jam sekali untuk melihat setiap perubahan yang terjadi selama penyimpanan

\section{Bagan Alir}

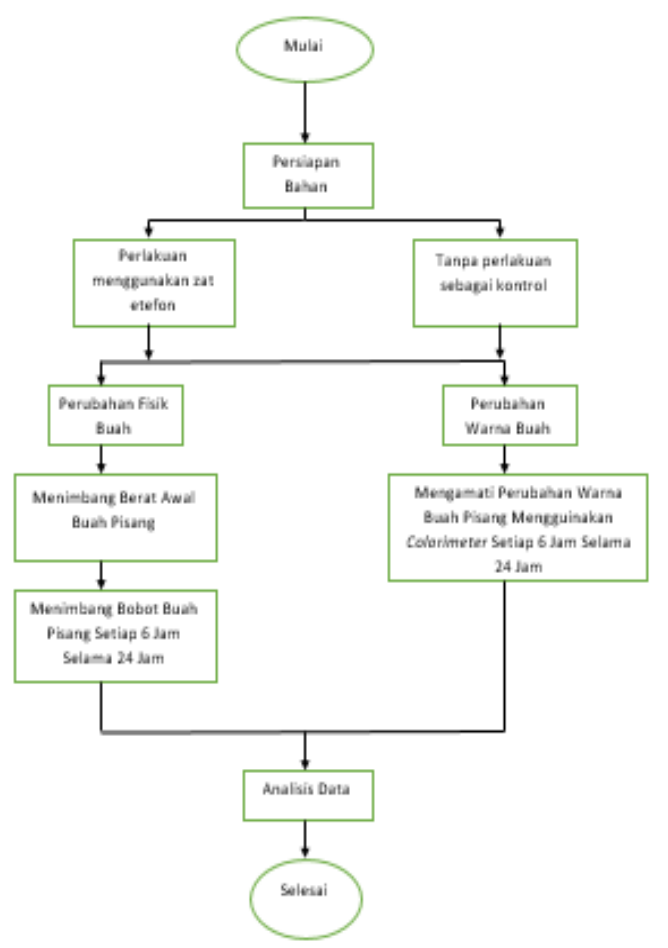

Gambar 4. Bagan Alir 


\section{HASIL DAN PEMBAHASAN}

\section{Karakteristik Buah Pisang}

Penelitian ini menggunakan buah pisang jenis kepok yang berasal dari Kabupaten Gowa kategori belum matang sebanyak enam buah. Tingkat kematangan buah di identifikasi melalui warna buah dan di ukur menggunakan colorimeter. Buah pisang yang masih muda umumnya berwarna hijau dengan nilai $L^{*}(40,73$ $53,68)$, nilai a* $(-7,38 .-17,30)$, serta nilai $b^{*}(27,96$ - 37,97) Adapun buah pisang yang digunakan berasal dari tandan yang sama, hal ini bertujuan untuk mengurangi adanya pengaruh perubahan sifat fisik buah pisang yang berbeda yang disebabkan perbedaan tandan. Adapun bobot buah pisang yang digunakan tidak seragam untuk setiap perlakuan penambahan etefon. Bobot buah pisang yang digunakan yaitu (120,2 129,38).

Parameter penelitian yang digunakan yaitu formulasi penambahan konsentrasi etefon untuk setiap pisang yang menjadi objek penelitian. Konsetrasi etefon yang digunakan pada penelitian ini yaitu: 10 $\mathrm{ml}, 15 \mathrm{ml}, 20 \mathrm{ml}, 25 \mathrm{ml}$ dan $30 \mathrm{ml}$. Pengukuran konsentrasi didasarkan pada penggunaan tutup botol dari produk etefon tersebut. Untuk takaran $10 \mathrm{ml}$ berarti menggunakan 1 tutup botol, untuk $15 \mathrm{ml}$ menggunakan 1,5 tutup botol begitu pula untuk konsentrasi $30 \mathrm{ml}$ menggunakan takaran 3 tutup botol.

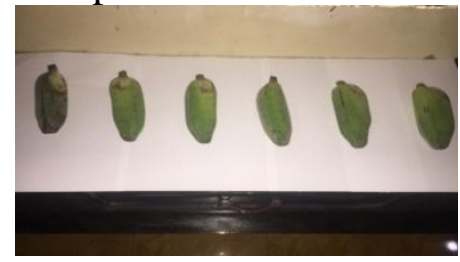

Gambar 7. Buah pisang kepok setelah hari

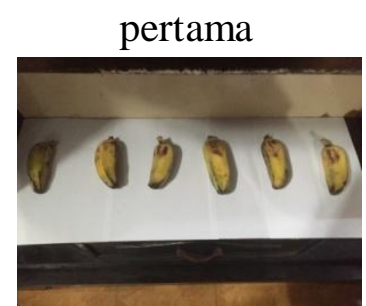

Gambar 8. Buah pisang kepok setelah masak

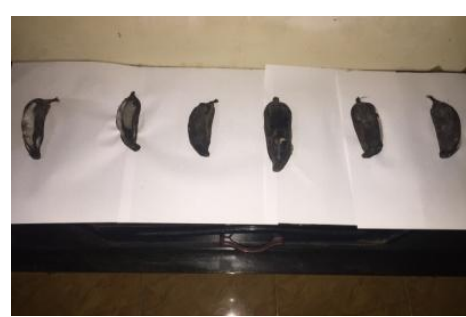

Gambar 9. Buah pisang kepok setelah busuk

Nilai L*

Nilai L* buah setelah diberikan zat etefon dengan perbandingan $10 \mathrm{ml}, 15 \mathrm{ml}$, $20 \mathrm{ml}, 25 \mathrm{ml}, 30 \mathrm{ml}$ dan tanpa perlakuan (kontrol) mengalami perubahan yang signifikan selama penyimpanan. Pola perubahan keseluruhan perlakuan hampir seragam yaitu menghasilkan data yang fluktuatif. Hal tersebut menunjukkan bahwa perlakuan pemberian jumlah etafon yang beragam tidak memberikan pengaruh yang signifikan.

Gambar 8 menunjukkan bahwa pola perubahan nilai $\mathrm{L}^{*}$ buah cenderung rendah pada hari pertama, dan cenderung meningkat pada hari ke-2, ke-3, dan kembali turun pada hari ke-4 sampai periode akhir penyimpanan. Hal itu disebabkan karena warna buah pada hari pertama penyimpanan adalah hijau, dan mulai menguning pada hari ke-2 dan ke-3 sehingga menghasilkan warna yang lebih cerah dari hari sebelumnya, dan pada hari ke empat sampai periode akhir penyimpanan warna buah menjadi hitam karena buah telah membusuk. Hal tersebut sesuai dengan pernyataan Gokmen (2007) yang menyatakan bahwa nilai L (Lightness) berkisar antara 0 sampai 100 , yaitu 0 berarti gelap atau hitam dan 100 berarti cerah atau putih.

Perlakuan terbaik yang menghasilkan nilai $\mathrm{L}^{*}$ tertinggi dari penelitian dapat dilihat pada konsentrasi zat etefon dengan konsentrasi sebesar $30 \mathrm{ml}$. Pada konsentrasi $30 \mathrm{ml}$ nilai $\mathrm{L}^{*}$ yang dihasilkan lebih tinggi dari perlakuan dengan konsentrasi lain, hal ini menunjukkan bahwa efek dari pemberian zat etefon memberikan pengaruh yang signifikan meskipun data yang dihasilkan fluktuatif. 


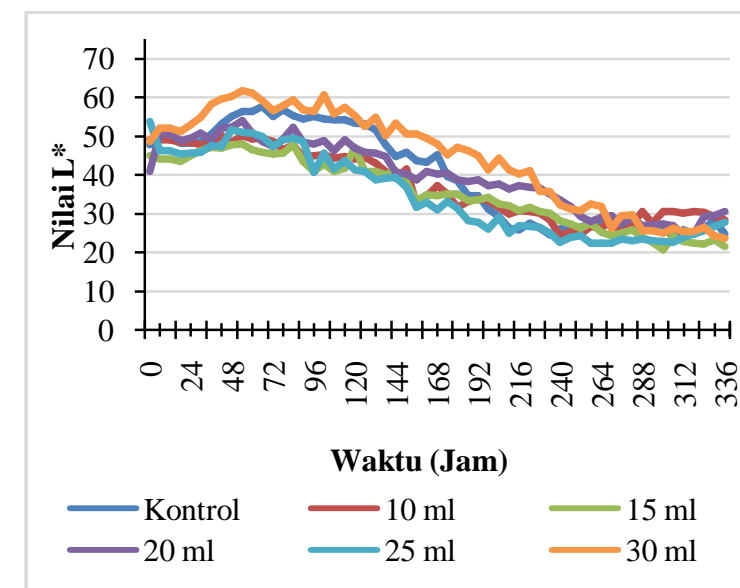

Gambar 8. Perbandingan Nilai L* Buah Dengan Perlakuan Berbeda Selama Penyimpanan

Nilai a*

Nilai a* buah dengan perlakuan berbeda yaitu pemberian zat etafon $10 \mathrm{ml}$, $15 \mathrm{ml}, 20 \mathrm{ml}, 25 \mathrm{ml}, 30 \mathrm{ml}$ dan tanpa pemberian (kontrol) menunjukkan perubahan yang signifikan dan menghasilkan data yang cenderung fluktuatif. Pola perubahan keseluruhan perlakuan hampir seragam dan tidak menunjukkan perbedaan yang signifikan. Hal itu menunjukkan bahwa perlakuan pemberian etafon yang beragam ataupun tanpa pemberian etafon tidak memberikan pengaruh yang signifikan terhadap nilai $\mathrm{a}^{*}$ buah.

Gambar 9 menunjukkan nilai $\mathrm{a}^{*}$ buah pada hari pertama adalah negative dan mengalami peningkatan setiap harinya, lalu turun pada periode pertengahan sampai akhir penyimpanan. Hal itu disebabkan karena pada hari pertama buah pisang masih segar dan keseluruhan kulit buah berwarna hijau sehingga menghasilkan nilai $\mathrm{a}^{*}$ yang negatif. Adapun pada hari ke tiga warna kulit buah cenderung menguning sehingga nilai a* buah terus meningkat dan kembali turun pada hari ke enam karena buah mulai mulai membusuk dan berubah menjadi lebih gelap. Hal tersebut sesuai dengan pernyataan Gokmen (2007) bahwa parameter kromatik yaitu nilai a* berkisar antara minus 120 sampai 120, yaitu nilai negatif mengindikasikan warna hijau dan nilai positif mengindikasikan warna merah.
Pemberian konsentrasi etefon berpengaruh signifikan pada berbagai jumlah konsentrasi yang telah ditetapkan pada penelitian ini, namun setiap konsentrasi pemberian etefon menghasilkan nilai yang fluktuatif. Meskipun pada hasil yang didapatkan dari grafik (Gambar 9) dilihat bahwa nilai a tertinggi didapatkan dari konsentrasi $15 \mathrm{ml}$. Namun tidak bisa disimpulkan bahwa pemberian konsentrasi berbeda mempengaruhi nilai $a^{*}$, karena konsentrasi pemberian etefon tertinggi terdapat pada konsentrasi $30 \mathrm{ml}$ tetapi nilai a pada konsentrasi $30 \mathrm{ml}$ merupakan yang terendah.

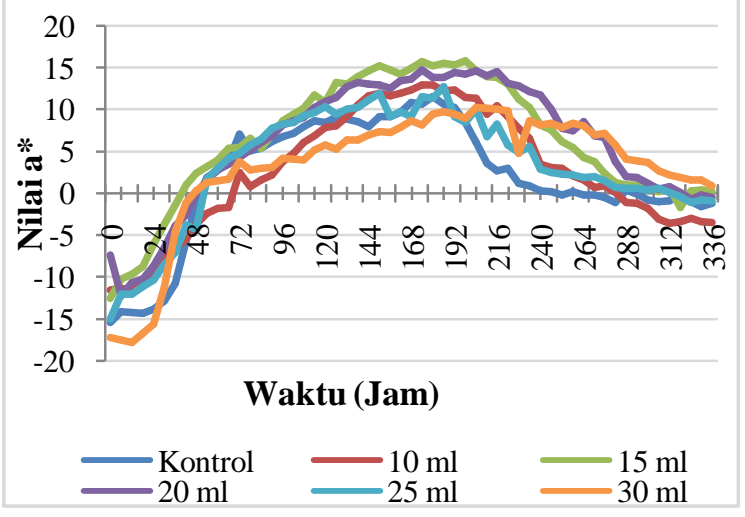

Gambar 9. Perbandingan Nilai a* Buah Dengan Perlakuan Berbeda Selama Penyimpanan

Nilai $b^{*}$

Nilai $b^{*}$ buah pisang dengan perlakuan berbeda yaitu pemberian zat etefon $10 \mathrm{ml}, 15 \mathrm{ml}, 20 \mathrm{ml}, 25 \mathrm{ml}, 30 \mathrm{ml}$, dan tanpa pemberian zat etafon (kontrol) menunjukkan perubahan yang signifikan selama penyimpanan dan menghasilkan data yang fluktuatif. Meskipun demikian, pola perubahan keseluruhan perlakuan cenderung seragam. Hal tersebut mengindikasikan bahwa perlakuan pemberian jumlah zat etafon yang beragam dan tanpa pemberian tidak memberikan pengaruh yang signifikan terhadap nilai $b^{*}$ buah pisang.

Gambar 10 menunjukkan nilai $b^{*}$ buah pisang cenderung naik pada periode awal penyimpanan dan menurun pada hari ke empat. Hal tersebut disebabkan karena pada hari pertama buah pisang masih dalam keadaan segar dan warna keseluruhan kulit buah adalah hijau. Sedangkan pada hari ke 
dua dan ke tiga, warna kulit buah mulai mengalami perubahan warna menjadi kuning sehingga terjadi peningkatan nilai $b^{*}$ pada hari tersebut. Adapun pada periode pertengahan sampai periode akhir penyimpanan warna kulit buah mulai menjadi gelap dan hitam karena buah mulai membusuk. Hal tersebut sesuai dengan pernyataan Gokmen (2007) bahwa parameter kromatik buah yaitu nilai $b^{*}$ berkisar antara minus 120 sampai 120, yaitu nilai negatif artinya perubahan warna menjadi biru dan nilai positif artinya perubahan warna menjadi kuning.

Perlakuan terbaik yang menghasilkan nilai $b^{*}$ tertinggi dari penelitian dapat dilihat pada konsentrasi zat etefon dengan konsentrasi sebesar $30 \mathrm{ml}$. Pada konsentrasi $30 \mathrm{ml}$ nilai $\mathrm{b}^{*}$ yang dihasilkan lebih tinggi dari perlakuan dengan konsentrasi lain, namun pola perubahan keseluruhan perlakuan cenderung seragam. hal ini menunjukkan bahwa efek dari pemberian zat etefon dan tanpa etefon tidak memberikan pengaruh yang signifikan.

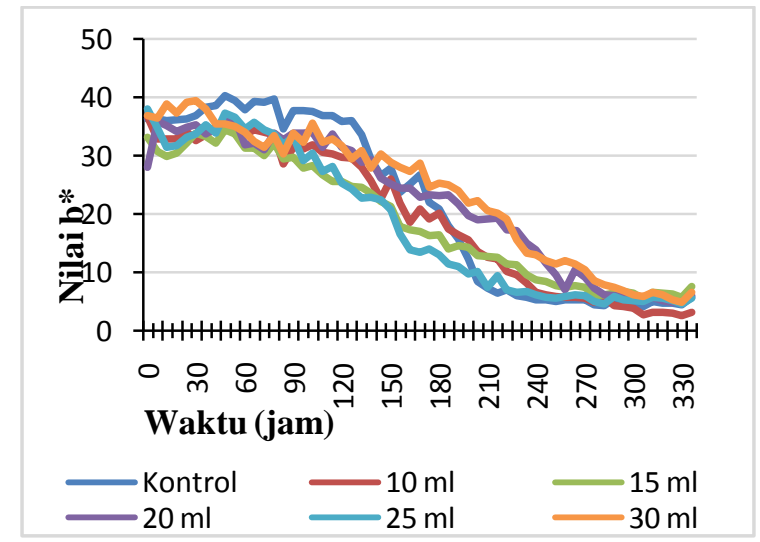

Gambar 10. Perbandingan Nilai $b^{*}$ Buah Dengan Perlakuan Berbeda Selama Penyimpanan

\section{Susut Bobot}

Susut bobot buah pisang dengan perlakuan berbeda yaitu pemberian zat etafon $10 \mathrm{ml}, 15 \mathrm{ml}, 20 \mathrm{ml}, 25 \mathrm{ml}, 30 \mathrm{ml}$, dan tanpa pemberian (kontrol) menunjukkan perubahan yang signifikan selama di simpan pada suhu ruang. Pola perubahan susut bobot buah tanpa pemberian zat etafon dengan pemberian 10 $\mathrm{ml}, 15 \mathrm{ml}$, dan $20 \mathrm{ml}$ tidak menunjukkan perbedaan yang signifikan. Berbeda dengan susut bobot buah dengan pemberian $25 \mathrm{ml}$ dan $30 \mathrm{ml}$ zat etafon yang menunjukkan perbedaan signifikan dengan buah yang berfungsi sebagai kontrol. Hal tersebut mengindikasikan bahwa pemberian zat etafon memberikan pengaruh yang signifikan terhadap susut bobot buah selama disimpan pada suhu ruang.

Gambar 11 menunjukkan bahwa susut bobot buah pisang yang berfungsi sebagai kontrol dan tanpa pemberian zat etafol memiliki susut bobot tertinggi yaitu mencapai $53 \%$ pada periode akhir penyimpanan. Adapun susut bobot terendah yaitu buah pisang dengan pemberian zat etafon $25 \mathrm{ml}$ dan $30 \mathrm{ml}$ yang tidak mencapai 40\%. Gambar 11 menunjukkan bahwa semakin banyak jumlah pemberian zat etafon maka susut bobot buah semakin berkurang dan tanpa pemberian zat etafon atau jumlah pemberian zat etafon yang sedikit menyebabkan susut bobot buah pisang meningkat.

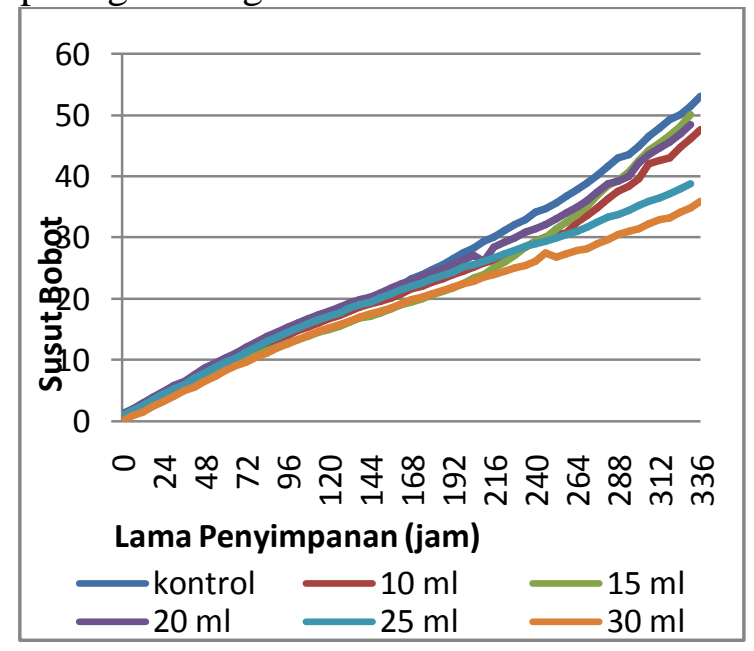

Gambar 11. Perbandingan susut bobot buah pisang dengan perlakuan berbeda selama penyimpanan.

\section{KESIMPULAN DAN SARAN}

\section{Kesimpulan}

Dari hasil penelitian pengaruh penggunaan zat etefon terhadap sifat fisik pisang kepok diperoleh kesimpulan sebagai berikut: 
1. Nilai yang dihasilkan tidak berbeda jauh antara tanpa pemberian zat etefon dan tiap perlakuan konsentrasi. Adapun nilai $\mathrm{L}^{*}$ terbaik pada konsentrasi $30 \mathrm{ml}$, nilai $\mathrm{a}^{*}$ terbaik pada konsentrasi $15 \mathrm{ml}$, nilai $\mathrm{b}^{*}$ terbaik konsentrasi $30 \mathrm{ml}$.

2. Nilai susut bobot tertinggi didapatkan pada perlakuan tanpa pemberian zat etefon.

3. Konsentrasi etefon $30 \mathrm{ml}$ menghasilkan proses pematangan buah pisang yang lebih cepat dari pada konsentrasi lainnya.

4. Nilai tertinggi pada susut bobot yaitu tanpa pemberian zat etefon dan yang terendah adalah $30 \mathrm{ml}$.

\section{Saran}

Sebaiknya penelitian ini di lanjut dengan menggunakan zat pematang yg berbeda agar dapat di bandingkan dengan zat pematang etefon.

\section{DAFTAR PUSTAKA}

Anonim ${ }^{1}$. 2011. Proses Pematangan Buah. Universitas Padjajaran: Bandunng. Azzamy. 2015. Apa Itu Zat Pengatur

Tumbuh (ZPT). http://mitalom. com.Diakses Hari Rabu, 18 Mei 2016.

BPS Sulawesi Selatan. 2015. Sulawesi Selatan dalam Angka 2015.

Badan Pusat Statistik Provinsi Sulawesi Selatan. Makassar.

Enrico. 2008. Optimasi Keadaan

Penyimpanan Buah Pepaya

Sebelum Pemeraman dengan

Algoritma Genetika. Institut

Pertanian Bogor: Bogor.

Gökmen,Vural., Hamide Z. Senyuva,

Berkan Dülek and Enis Çetin.

2007.Compuer Vision Based

Analysis of Potato Chips-A Tool

for Rapid Detection of Acrylamide

level. www.sciencedirect.com.

Diakses Hari Rabu, 18 Mei 2016.

H.helmi. 2011. Pengertian suhu.

Universitas Sumatra Utara: Medan.

Hardiyanti. 2009. Warna Alami. Jurusan

Geografi. Fakultas Matematika dan
Ilmu Pengetahuan Alam.

Universitas Negeri Makassar:

Makassar.

Holinesti. 2009. Studi Pemanfaatan Pigmen

Brazilein Kayu Secang

(Caesalpinia Sappan L.) Sebagai

Pewarna Alami Serta Stabilitasnya

Pada Model Pangan. Jurnal

Pendidikan Dan Keluarga Unp,

Vol. I,No. 2, Page 11-21.

Leön. 2005. Color Measurement In $L * A * B *$

Units From Rgb Digital Images .

Publication In Journal Of Food

Engineering Vol. I, Page 1-23.

Muhajir Imam dan Sanuki Pratikno. 1998.

Pengaruh Pembrongsongan dan

Pestisida Terhadap Hama Penyakit

Pascapanen dan Mutu Buah Pisang

Ambon Kuning Selama

Pematangan.J.Hort. 8(3):1217-

1232.

Murtiningsih, Prabawati. S, dan I. Muhajir.

1995. Kapang penyebab busuk

crown pada pisang Raja

bulu dan cara pengendaliannya. J.

Hort 5(3): 70-75.

Murtiningsih, Suyanti dan I.Muhajir. 1990.

Pengaruh Umur Petik Pisang

Ambon Jepang Terhadap Mutu

Tepung. Penelitian Hortikultura 5(2):93-98.

Murtiningsih, Yulianingsih dan I.Muhajir. 1991. Penyakit Pascapanen Pada

Buah Pisang Raja Sere, Emas dan

Lampung Serta Pengendaliannya.

J. Hort 1(3) 35-38.

M. Rahmad Suhartanto., Sobir, dan Heri

Harti. 2012. Teknologi Sehat

Budidaya Pisang. Institut Pertanian

Bogor: Bogor.

Ngasih. 2014.Zat Perangsang Pemasakan

(Pematangan) Buah. http://www.

ngasih .com/2014 /11/29/zat-

perangsang-pemasakan-

pematangan-buah/\#ixzz48sxS

7rDn. Diakses Hari Rabu, 18 Mei

2016.

Pangestuti R. 2004. Pengaruh Suhu

Penyimpanan Terhadap

Perubahan Kualitas Dan Umur 
Simpan Buah Jeruk Keprok Soe (Citrus Reticulata Blanco) Pada Umur Petik Yang Berbeda. Balai Penelitian Tanaman Jeruk Dan Buah Subtropika: Nusa Tenggara Timur.

Purwono. 2002. Penggunaan Pengukuran

Brix untuk Menduga Rendemen Nyata Di Pabrik Gula Gula Putih Mataram, Lampung. Divisi R \& D, Pabrik Gula Gula Putih Mataram: Lampung.

Raimundus R, Ginting, Sitawati dan Y.B, Suwasono Heddy. 2015. Zat

Pengatur Tumbuh.Fakultas pertanian Universitas Brawijaya: Malang

Satuhu, Suyanti. 1996. Budidaya

Pengolahan dan Prospek Pasar

Pisang. Penebar swadaya: Jakarta.

Satuhu Suyanti, dan Ahmad Supriyadi. 2008. Pisang Budidaya, Pengolahan dan Prospek Pasar. Penebar swadaya: Jakarta.

Suharto. 1991. Teknologi Pengawetan Pangan. PT. Rineka Cipta: Jakarta. Sulusi Prabawati, Suyanti dan Dondy A Setyabudi. 2008.Teknologi Pasca Panen dan Teknik Pengolahan Buah Pisang, Balai Besar Penelitan dan Pengembangan Pascapanen Pertanian Badan Penelitan dan Pengembangan Pertanian (Juknis Pisang).Bumi Aksara: Jakarta.

Syange. 2013. Horticulture. http://www. britannica.com/Ebchecked/topic/27 .2484/ho rticulture/34656/Growthregulation-by-chemicals. Diakses Hari selesa 20 Desember 2016

Tjitrosoepomo. 1991. Klasifikasi Tanaman Pisang Kepok. Universitas lampung:Lampung.

Winarno. F.G. 1992. Kimia Pangan dan Gizi. PT.Gramedia Utama: Jakarta. 